\title{
Classification of Post-Fire Responses of Woody Plants to include Pyrophobic Communities
}

\author{
Lynda D. Prior * and David M. J. S. Bowman \\ School of Natural Resources, University of Tasmania, Private Bag 55, Hobart, Tasmania 7001, Australia; \\ david.bowman@utas.edu.au \\ * Correspondence: lynda.prior@utas.edu.au
}

Received: 24 April 2020; Accepted: 19 May 2020; Published: 20 May 2020

\begin{abstract}
Developing standardised classification of post-fire responses is essential for globally consistent comparisons of woody vegetation communities. Existing classification systems are based on responses of species growing in fire-prone environments. To accommodate species that occur in rarely burnt environments, we have suggested some important points of clarification to earlier schemes categorizing post-fire responses. We have illustrated this approach using several Australasian conifer species as examples of pyrophobic species. In particular, we suggest using the term "obligate seeder" for the general category of plants that rely on seed to reproduce, and qualifying this to "post-fire obligate seeder" for the narrower category of species with populations that recover from canopy fire only by seeding; the species are typically fire-cued, with large aerial or soil seed banks that germinate profusely following a fire, and grow and reproduce rapidly in order to renew the seed bank before the next fire.
\end{abstract}

Keywords: Athrotaxis; Australian conifers; Callitris; canopy fire; obligate seeder; resprouting; high-severity fire

Fire presents a powerful filter of plant populations and hence shapes the geographic pattern and dynamics of plant communities. Reflecting such strong selection pressure, post-fire regeneration involves a diverse range of sexual and vegetative strategies across numerous plant lineages [1-5]. Developing standardised classification of post-fire responses is an essential step to enable globally consistent comparative biogeographic and functional analyses. Existing classification systems have focussed on plants growing in ecosystems in which canopy-defoliating fire has been an important evolutionary force, such as heathlands growing in Mediterranean climates. For example, the four categories of fire response derived by Pausas and Keeley [4] explicitly apply to responses to canopy-defoliating fire, usually in reference to species in fire-prone environments. However, with changes in climate and land management, fire has become more prevalent in ecosystems that have previously experienced very little fire, such as rainforests and sub-alpine regions [6,7], so a broader classification of post-fire response is needed to accommodate species in these environments. Therefore, we propose a modification of the classification of post-fire recovery strategies developed by Pausas and co-workers [3,4] and Clarke et al. [5], using several fire-intolerant Australasian conifers as examples.

Early classification schemes often treated the response of long-lived plants to fire as dichotomous, whereby taxa in fire-prone vegetation either resprout (resprouters) or are killed by fire and rely on seed to regenerate (obligate seeders) $[1,2,5]$. It has been subsequently recognised that resprouting and regeneration from seed are functionally independent traits, with many plant species capable of either or both $[4,5]$. Current classifications of plant responses, therefore, are based on the presence or absence of two traits: resprouter vs. non-resprouter ( $\mathrm{R}+\mathrm{vs}$. $\mathrm{R}-$ ) and postfire seeding vs. no postfire seeding (S+ 
vs. S-), leading to four potential categories of postfire responses, termed obligate resprouters (R+S-), facultative seeders $(\mathrm{R}+\mathrm{S}+$ ), obligate seeders (R-S+), and fire avoiders (R-S-) by Clarke et al. [5]. (The equivalent terms proposed by Pausas and Keeley [4] are, for $\mathrm{R}+\mathrm{S}+$, facultative resprouters and, for R-S-, postfire colonisers; it is assumed that R-S- species that are not colonisers cannot persist in such environments, and are simply considered fire-intolerant). It is important to note that these terms were defined specifically in relation to responses to canopy-defoliating fire; thus the terms "seeder" and "obligate seeder" were reserved for plants that regenerate by seed post-fire, and not for plants that regenerate by seeds in other conditions [4]. Furthermore, embedded in the schemes of Clarke et al. [5] and Pausas and Keeley [4] is an assumption that "seeding" is fire-cued, and that "seeder species" have a seed bank that is long-lived ( $>1$ year); the release and/or germination of their seeds is stimulated by fire, and/or they display immediate postfire recruitment from seed [5]. Thus, establishment of seedlings after fire is confounded with fire-cued seedling production. This is reflected in the current use of the term "obligate seeders" as plants with large, fire-activated seed banks that germinate, grow, and mature rapidly following a fire, in order to reproduce and renew the seed bank before the next fire [4].

Here, we broaden the scope of schemes that describe post-fire recovery strategies to accommodate communities assumed to be occupied by "fire-intolerant" species. This is based on the presence or absence of traits affecting post-fire resprouting, seeding and colonization ability. Table 1 compares our classes with equivalent terms used by Pausas and co-workers [3,4] and Clarke et al. [5]. The most important change we propose concerns the definition of seeders.

Table 1. Terminology proposed here to describe woody plant responses to canopy-defoliating fire, and comparison with earlier schemes. Relevant traits, listed in brackets, are as follows (our scheme): $\mathrm{R}$ is resprouter, $R_{f}$ is post-fire resprouter, $S$ is seeder, $S_{f}$ is post-fire seeder, $C$ is colonizer. Traits used in earlier schemes: $\mathrm{R}$ is post-fire resprouting; $\mathrm{P}$ is propagule persistence; $\mathrm{S}$ is post-fire seeding.

\begin{tabular}{|c|c|c|c|c|}
\hline Proposed Terminology & Definition & Pausas et al. [3] & Pausas \& Keeley [4] & Clarke et al. [5] \\
\hline \multicolumn{5}{|c|}{ General responses } \\
\hline Obligate seeder (R-S+) & $\begin{array}{l}\text { Does not resprout and reproduces exclusively } \\
\text { from seed. Not all produce seedlings after } \\
\text { severe fire. }\end{array}$ & - & - & - \\
\hline $\begin{array}{l}\text { Obligate resprouter } \\
\qquad(\mathrm{R}+\mathrm{S}-)\end{array}$ & $\begin{array}{l}\text { Does not produce seed, reproduces clonally. } \\
\text { Not all resprout after severe fire. }\end{array}$ & - & - & - \\
\hline \multicolumn{5}{|c|}{ Post-fire responses } \\
\hline $\begin{array}{l}\text { Post-fire obligate seeder } \\
\qquad\left(\mathrm{R}_{\mathrm{f}}-\mathrm{S}_{\mathrm{f}}+\right)\end{array}$ & $\begin{array}{l}\text { Does not resprout but regenerates (often } \\
\text { prolifically) from seed after fire. Fire-tolerant at } \\
\text { a population, but not at an individual, level. }\end{array}$ & $\begin{array}{l}\text { Obligate seeder } \\
\qquad(\mathrm{R}-\mathrm{P}+)\end{array}$ & $\begin{array}{l}\text { Obligate seeder } \\
\quad(\mathrm{R}-\mathrm{P}+)\end{array}$ & $\begin{array}{l}\text { Obligate seeder } \\
\quad(\mathrm{R}-\mathrm{S}+)\end{array}$ \\
\hline $\begin{array}{l}\text { Post-fire facultative } \\
\text { resprouter/seeder } \\
\quad\left(\mathrm{R}_{\mathrm{f}}+\mathrm{S}_{\mathrm{f}}+\right)\end{array}$ & $\begin{array}{l}\text { Both resprouts and produces seedlings after } \\
\text { fire. }\end{array}$ & $\begin{array}{l}\text { Facultative species } \\
\qquad(\mathrm{R}+\mathrm{P}+)\end{array}$ & $\begin{array}{l}\text { Facultative seeder } \\
\qquad(\mathrm{R}+\mathrm{P}+)\end{array}$ & $\begin{array}{l}\text { Facultative } \\
\text { resprouter } \\
(\mathrm{R}+\mathrm{S}+)\end{array}$ \\
\hline $\begin{array}{l}\text { Post-fire obligate } \\
\text { coloniser } \\
\left(\mathrm{R}_{\mathrm{f}}-\mathrm{S}_{\mathrm{f}}-\mathrm{C}+\right)\end{array}$ & $\begin{array}{l}\text { Neither resprouts nor produces seedlings } \\
\text { post-fire but is able to colonise burnt areas by } \\
\text { dispersal from areas not burnt by high-severity } \\
\text { fire. Fire-tolerant at a meta-population level }\end{array}$ & \multirow[t]{2}{*}{$\begin{array}{l}\text { Species that do not } \\
\text { persist after fire } \\
\text { (R-P-) }\end{array}$} & $\begin{array}{l}\text { Postfire colonizer } \\
\text { (R-P-) }\end{array}$ & \multirow[t]{2}{*}{$\begin{array}{l}\text { Fire-avoider } \\
\quad \text { (R-S-) }\end{array}$} \\
\hline $\begin{array}{l}\text { Fire-intolerant } \\
\left(\mathrm{R}_{\mathrm{f}}-\mathrm{S}_{\mathrm{f}}-\mathrm{C}-\right)\end{array}$ & $\begin{array}{l}\text { Populations unable to recover by post-fire } \\
\text { resprouting, seeding or colonisation }\end{array}$ & & - & \\
\hline
\end{tabular}

Pausas and Keeley [4] reserved use of the terms "seeder" and "obligate seeder" for plants that regenerate by seed post-fire, stating that they cannot be used for plants that regenerate by seeds in other conditions. We recommend using the more accurate and explicit terms "post-fire seeder" and "post-fire obligate seeder". This is in keeping with the dictionary definition of a "seeder" as a plant that produces seeds, and of "obligate", which means restricted to a particular mode of life, habitat, or 
function [8]; hence, an "obligate seeder" is a species that can regenerate only from seed. A post-fire obligate seeder does not resprout, but, after fire, it regenerates from seed. Its seed germination is often fire-cued and prolific. Post-fire obligate seeders are fire-tolerant at a population, but not at an individual, level. Analogously, in the context of fire ecology, we have qualified "obligate resprouter" as "post-fire obligate resprouter". A post-fire obligate resprouter survives complete fire-induced defoliation by resprouting and does not produce seedlings post-fire. It is fire-tolerant at an individual as well as a population level. Post-fire obligate colonisers neither resprout nor produce seedlings post-fire but are able to colonise burnt areas by dispersal from areas not burnt by high-severity fire. These species are fire-tolerant at a meta-population level. We also use the composite category "fire-intolerant", which includes fire-intolerant obligate seeders, fire-intolerant obligate resprouters and fire-intolerant facultative resprouters/seeders that are not readily able to colonise from nearby unburnt areas. It is important to recognise that, although our categorisation is binary, responses can fall on a spectrum from a weak to a strong resprouter. For example, some species resprout after disturbances such as insect attack, drought or surface fire, but not after severe fire [9]. We suggest reserving the term "post-fire resprouter" for species which reliably resprout after canopy-defoliating fire. A suitable operational definition could be a species in which at least $50 \%$ of individuals resprout following canopy-defoliating fire. In addition to fire severity, population responses can vary according to factors such as fire size, because colonisation from unburnt populations is more difficult when a larger area is burnt.

Note that seeders can be further categorised according to whether or not they are serotinous (i.e. their seed remains on the plant after maturity, and is released after an environmental trigger), a feature that can promote prolific seedling regeneration following fire or drought [10]. Post-fire obligate seeders require a long-lived, fire-resistant seedbank, either in the canopy or in the soil, to allow seedling production after fire. Another important feature of seeders is whether they are good colonisers of disturbed areas; this is influenced by their dispersal ability and is crucial in determining a species' tolerance to fire at a metapopulation level.

There are environments such as rainforests and alpine areas where severe fire is relatively infrequent, and not a dominant evolutionary force on the species they contain. Such species are found on all vegetated continents, but, here, we use some Australasian conifer species to illustrate the need to more precisely describe the various effects of fire in species that have not been subject to strong selection pressure by fire, although they often persist in refugia surrounded by fire-prone landscapes. Unsurprisingly, many of these species from fire-protected environments appear to be fire-intolerant. A good example of a fire-intolerant facultative resprouter/seeder is the Tasmanian sub-alpine conifer Athrotaxis cupressoides. It is a mast-seeder and lacks a soil or aerial seedbank, and root-suckering is an important mode of regeneration (Figure 1a-c). It is highly susceptible to crown fires, with high individual mortality, very limited resprouting and often no seedling regeneration, so many populations have been eliminated by fires in the period since European settlement [7]. By contrast, Podocarpus drouynianus, a common understorey shrub in flammable Eucalyptus diversicolor forests, resprouts from its rootstock and produces small male and female cones, allowing persistence of populations after fire. Thus, unlike all of its fire-sensitive congeners, it is a post-fire facultative resprouter/seeder, possibly reflecting adaptation to more flammable environment [11]. Recent bushfires have revealed that the Wollemi pine (Wollemia nobilis), a clonal species that survived for thousands of years in several small fire-protected refugia in rugged country in eastern Australia, aerially resprouts after complete defoliation by fire (Bradstock pers. comm. 2020), so it could be potentially considered a post-fire obligate resprouter.

Several dryland species of the important genus Callitris have very limited vegetative recovery following disturbance and rely on seed for regeneration, and they are therefore obligate seeders in the dictionary sense of the term [12]. Yet, there are crucial differences in the type of seeding response to fire disturbance. For instance, Callitris glaucophylla grows in woodlands subject to periodic severe fire. It is not serotinous, lacks a long-lived soil seedbank and is poorly dispersed $[13,14]$. As a consequence, it regenerates only during fire-free intervals, and is locally eliminated by high-severity 
fires [14]. Its congener, Callitris intratropica, also lacks a long-lived seedbank and is poorly dispersed [14]. It grows in savannas, which are subject to frequent surface fires. Mature trees can survive low-severity fires, but are killed by severe fire, and in recent years many populations have been eliminated by increased-severity fire. By contrast, Callitris verrucosa, which has an overlapping geographic range with C. glaucophylla, is serotinous and regenerates prolifically following canopy fire [13,15], creating even-aged stands. Thus, while the three taxa are obligate seeders, only C. verrucosa is a "post-fire obligate seeder"; C. glaucophylla and C. intratropica are "fire-intolerant obligate seeders". Similarly, their New Caledonian rainforest congener Callitris sulcata, which has not evolved with fire and is poorly adapted to it, can only regenerate from seed and can also be considered a 'fire-intolerant obligate seeder' [16]. Highlighting the fact that plant responses are seldom absolute, we note that some Callitris species are able to very weakly resprout after fire (Figure 1d-e); it is unknown why species in this clade that grow in fire-prone environments have not evolved more robust aerial resprouting.

(a)

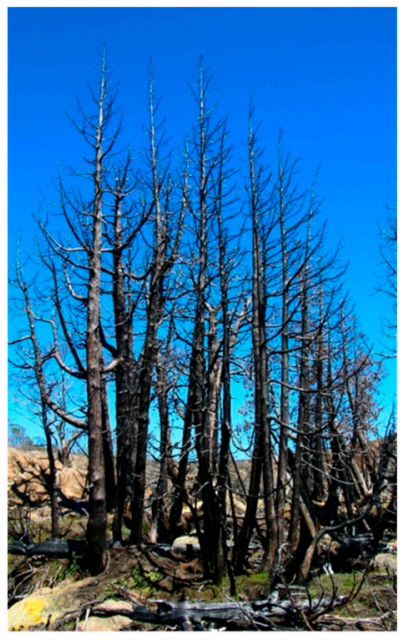

(c)

(b)

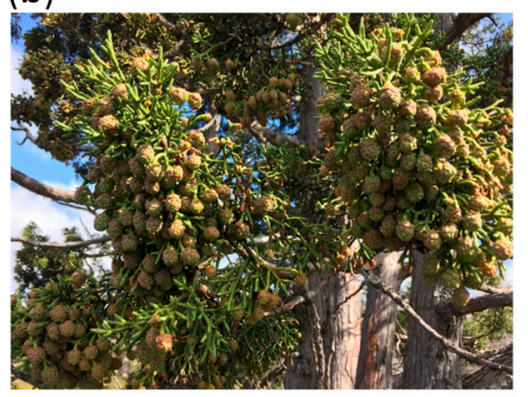

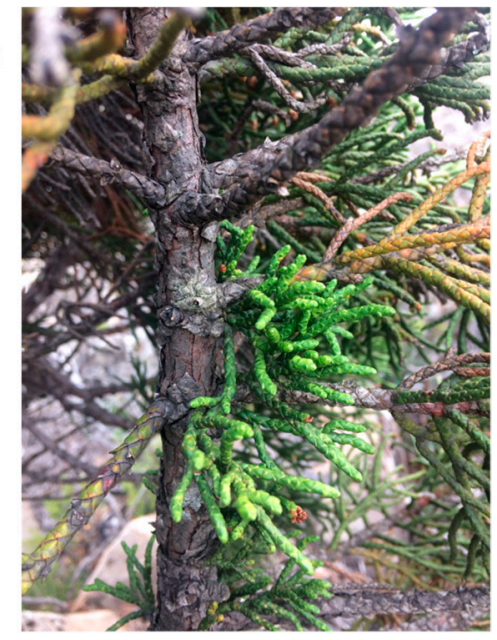

(d)

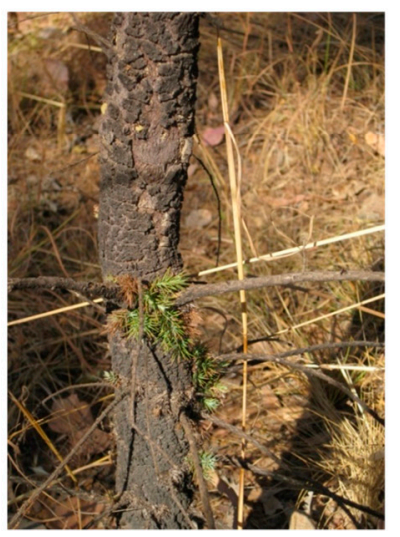

(e)

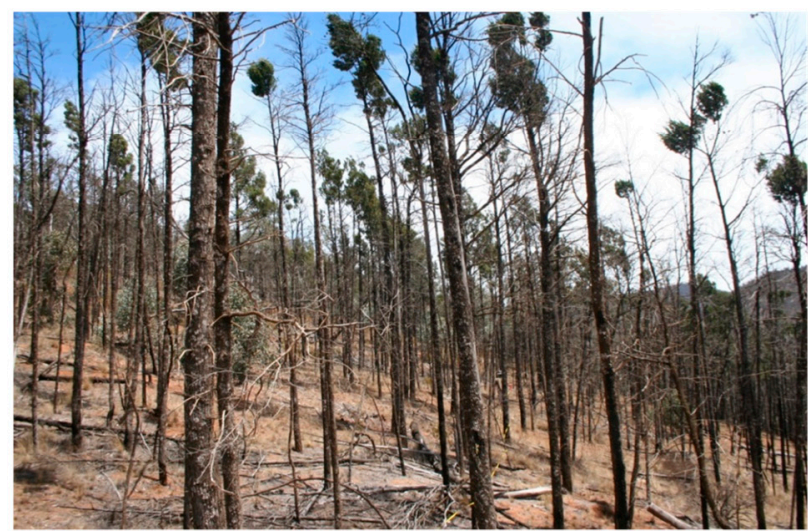

Figure 1. Resprouting response after fire is not binary, but falls on a continuum, as illustrated by some fire-intolerant Australian conifer species. (a) Athrotaxis cupressoides, endemic to sub-alpine areas of Tasmania, can form extensive clumps through clonal regeneration, but (b) is also a mast seeder. It is a facultative resprouter/seeder that is intolerant of canopy fire, but (c) a few stems have resprouted after severe fire in 2016. In drier regions of Australia, the fire-intolerant obligate seeders (d) Callitris intratropica and (e) Callitris glaucophylla, usually regarded as non-resprouters, can also weakly resprout after canopy fire. Photos: (a)-(c), Aimee Bliss, and (d)-(e), Lynda Prior.

In conclusion, to accommodate species that occur in rarely burnt environments, we have suggested some minor, albeit important, points of clarification to earlier schemes categorizing post-fire responses [2-5]. We have illustrated this approach using several Australian conifer species as examples. The most important change is to explicitly recognise different types of "obligate seeders". 
We acknowledge that our proposal is a small amendment to existing schemes, designed to include a greater range of plant species' post-fire responses, particularly from pyrophobic communities. However, we suggest that our modifications are important because precise terminology of post-fire responses is essential to understand the evolution of fire recovery strategies. We expect these schemes to continue to develop in order to capture more subtle post-fire responses (Figure 1). These are affected by other factors such as plant age and size [17,18], fire severity and frequency [18-20], location [21], and the interaction with physiological stress, particularly drought $[22,23]$. Incorporating these effects into post-fire responses remains a research frontier.

Author Contributions: Conceptualisation, D.M.J.S.B. \& L.D.P.; writing-original draft preparation, L.D.P. \& D.M.J.S.B.; writing - review and editing, L.D.P. \& D.M.J.S.B. Both authors have read and agreed to the published version of the manuscript.

Funding: This research received no external funding.

Conflicts of Interest: The authors declare no conflict of interest.

\section{References}

1. Gill, A.M. Adaptive responses of Australian vascular plant species to fires. In Fire and the Australian Biota; Gill, A.M., Groves, R.H., Noble, I.R., Eds.; Australian Academy of Science: Canberra, Australia, 1981; pp. 243-271.

2. Bond, W.; Midgley, J.J. Ecology of sprouting in woody plants: The persistence niche. Trends Ecol. Evol. 2001, 16, 45-51. [CrossRef]

3. Pausas, J.G.; Bradstock, R.A.; Keith, D.A.; Keeley, J. Plant Functional Traits in Relation to Fire in Crown-Fire Ecosystems. Ecology 2004, 85, 1085-1100. [CrossRef]

4. Pausas, J.G.; Keeley, J. Evolutionary ecology of resprouting and seeding in fire-prone ecosystems. New Phytol. 2014, 204, 55-65. [CrossRef] [PubMed]

5. Clarke, P.J.; Lawes, M.; Murphy, B.P.; Russell-Smith, J.; Nano, C.E.M.; Bradstock, R.; Enright, N.J.; Fontaine, J.B.; Gosper, C.R.; Radford, I.; et al. A synthesis of postfire recovery traits of woody plants in Australian ecosystems. Sci. Total. Environ. 2015, 534, 31-42. [CrossRef] [PubMed]

6. Cochrane, M.A. Fire science for rainforests. Nature 2003, 421, 913-919. [CrossRef] [PubMed]

7. Bowman, D.M.J.S.; Bliss, A.; Bowman, C.J.W.; Prior, L.D. Fire caused demographic attrition of the Tasmanian palaeoendemic conifer Athrotaxis cupressoides. Austral. Ecol. 2019, 44, 1322-1339. [CrossRef]

8. Oxford English Dictionary. Available online: https://www.oed.com/ (accessed on 12 November 2019).

9. Vesk, P.A.; Westoby, M. Sprouting ability across diverse disturbances and vegetation types worldwide. J. Ecol. 2004, 92, 310-320. [CrossRef]

10. Causley, C.L.; Fowler, W.M.; Lamont, B.B.; He, T.H. Fitness benefits of serotiny in fire- and drought-prone environments. Plant Ecol. 2016, 217, 773-779. [CrossRef]

11. Beard, J.S. Plant Life of Western Australia; Kangaroo Press: Kenthurst, Australia, 1990.

12. Bowman, D.M.J.S.; Harris, S. Conifers of Australia's dry forests and open woodlands. In Ecology of the Southern Conifers; Enright, N.J., Hill, R.S., Eds.; Melbourne University Press: Melbourne, Australia, 1995; pp. 252-270.

13. Ladd, P.G.; Midgley, J.J.; Nield, A.P. Serotiny in southern hemisphere conifers. Aust. J. Bot. 2013, 61, 486-496. [CrossRef]

14. Prior, L.D.; McCaw, L.; Grierson, P.F.; Murphy, B.P.; Bowman, D. Population structures of the widespread Australian conifer Callitris columellaris are a bio-indicator of continental environmental change. For. Ecol. Manag. 2011, 262, 252-262. [CrossRef]

15. Bradstock, R.; Cohn, J.S. Demographic characteristics of mallee pine (Callitris verrucosa) in fire-prone mallee communities of central New South Wales. Aust. J. Bot. 2002, 50, 653-665. [CrossRef]

16. Haverkamp, C.; Prior, L.D.; Fogliani, B.; L’Huillier, L.; Anquez, M.; Hua, Q.; Bowman, D. Effect of landscape fires on the demography of the endangered New Caledonian conifer Callitris sulcata. Boil. Conserv. 2015, 191, 130-138. [CrossRef]

17. Vesk, P.A. Plant size and resprouting ability: Trading tolerance and avoidance of damage? J. Ecol. 2006, 94, 1027-1034. [CrossRef] 
18. Fairman, T.; Bennett, L.T.; Nitschke, C. Short-interval wildfires increase likelihood of resprouting failure in fire-tolerant trees. J. Environ. Manag. 2019, 231, 59-65. [CrossRef] [PubMed]

19. Nicholson, Á.; Prior, L.D.; Perry, G.L.W.; Bowman, D.M.J.S. High post-fire mortality of resprouting woody plants in Tasmanian Mediterranean-type vegetation. Int. J. Wildland Fire 2017, 26, 532-537. [CrossRef]

20. Poulos, H.M.; Barton, A.M.; Slingsby, J.A.; Bowman, D. Do Mixed Fire Regimes Shape Plant Flammability and Post-Fire Recovery Strategies? Fire 2018, 1, 39. [CrossRef]

21. Vivian, L.M.; Doherty, M.D.; Cary, G.J. Classifying the fire-response traits of plants: How reliable are species-level classifications? Austral. Ecol. 2010, 35, 264-273. [CrossRef]

22. Clarke, P.J.; Lawes, M.; Midgley, J.J.; Lamont, B.; Ojeda, F.; Burrows, G.E.; Enright, N.J.; Knox, K.J.E. Resprouting as a key functional trait: How buds, protection and resources drive persistence after fire. New Phytol. 2012, 197, 19-35. [CrossRef] [PubMed]

23. Pratt, R.B.; Jacobsen, A.L.; Ramirez, A.R.; Helms, A.M.; Traugh, C.A.; Tobin, M.F.; Heffner, M.S.; Davis, S.D. Mortality of resprouting chaparral shrubs after a fire and during a record drought: Physiological mechanisms and demographic consequences. Glob. Chang. Boil. 2013, 20, 893-907. [CrossRef] [PubMed]

(C) 2020 by the authors. Licensee MDPI, Basel, Switzerland. This article is an open access article distributed under the terms and conditions of the Creative Commons Attribution (CC BY) license (http://creativecommons.org/licenses/by/4.0/). 